\title{
Knowledge about hereditary nonpolyposis colorectal cancer; mutation carriers and physicians at equal levels Katarina Domanska*1, Christina Carlsson ${ }^{1}$, Pär-Ola Bendahl ${ }^{1}$ and Mef Nilbert ${ }^{1,2}$
}

\author{
Address: ${ }^{1}$ Department of Oncology, Institute of Clinical Sciences, Lund University, Sweden and ${ }^{2}$ Clinical Research Centre, Hvidovre Hospital \\ Copenhagen University, Hvidovre, Denmark \\ Email: Katarina Domanska* - katarina.domanska@med.lu.se; Christina Carlsson - christina.carlsson@med.lu.se; Pär-Ola Bendahl - par- \\ ola.bendahl@med.lu.se; Mef Nilbert - mef.nilbert@med.lu.se \\ * Corresponding author
}

Published: 26 March 2009

BMC Medical Genetics 2009, 10:30 doi:10.1 186/147/-2350-10-30

This article is available from: http://www.biomedcentral.com/I47I-2350/10/30

(C) 2009 Domanska et al; licensee BioMed Central Ltd.

This is an Open Access article distributed under the terms of the Creative Commons Attribution License (http://creativecommons.org/licenses/by/2.0), which permits unrestricted use, distribution, and reproduction in any medium, provided the original work is properly cited.
Received: 26 December 2008

Accepted: 26 March 2009

\begin{abstract}
Background: Identification and adequate management of individuals at risk for hereditary nonpolyposis colorectal cancer (HNPCC) is crucial since surveillance programmes reduce morbidity and mortality. We investigated knowledge about key features of HNPCC in at risk individuals and physicians in surgery, gynecology and oncology.
\end{abstract}

Methods: Data were collected using a questionnaire which was answered by 67 mutation carriers and 102 physicians from the southern Swedish health care region. The statements were related to colorectal cancer, heredity and surveillance and the physicians were also asked questions about cancer risks and surveillance strategies.

Results: Both groups answered questions on colorectal cancer risk, surveillance and genetic testing well, whereas answers about inheritance and risks for HNPCC associated cancer were less accurate. Only half of the family members and one third of the physicians correctly estimated the risk to inherit an HNPCC predisposing mutation. Among family members, young age ( $<57$ years), female sex and recent genetic counseling significantly correlated with better results. Physicians generally underestimated the risk of HNPCC associated cancers and three out of four suggested a later starting age for surveillance than recommended.

Conclusion: The finding of similar levels of knowledge about key features of HNPCC in at risk individuals and physicians reflect the challenge physicians face in keeping up to date on hereditary cancer and may have implications for the clinical management and professional relations with HNPCC family members.

\section{Background}

Clinicians are increasingly expected to be familiar with hereditary cancer, including diagnostic criteria, the genetic testing process and recommendations for surveillance and surgery. Though physicians cannot be expected to have detailed knowledge of causative genes and testing platforms, it remains their responsibility to identify at risk individuals and recommend appropriate surveillance. Strategies here for have been adopted by several medical societies and are of particular relevance for physicians in 
primary health care, surgery, gynecology and oncology [1$6]$. At the same time, members in families with hereditary cancer are increasingly well informed through various educational programmes, printed information, internet sites and a growing number of patient associations. Knowledge about hereditary cancer is central and has been demonstrated to correlate with participation in surveillance programmes $[1,7,8]$.

Hereditary nonpolyposis colorectal cancer (HNPCC) is the most common form of hereditary colon cancer with an estimated prevalence of $1 / 2000$ [9]. Colorectal cancer predominates with a life time risk of $60-90 \%$, but female mutation carriers are also at increased risk of gynecological cancer, with a $40-60 \%$ risk of endometrial cancer and a $5-15 \%$ risk of ovarian cancer $[3,10-13]$. Various rare tumor types, e.g. cancer in the upper urothelial tract, the small intestine, gastric cancer, brain tumor and skin tumors have also been linked to HNPCC, but the life time risks for these tumors are $<5 \%[10,14-18]$.

Several features are indicative of HNPCC, e.g. development of multiple HNPCC associated cancers in a family, young age at diagnosis, synchronous and metachronous tumors and certain morphological characteristics. In order to facilitate diagnosis and classification of HNPCC, various guidelines have been developed. The most widely used are the Bethesda guidelines aimed at identifying tumors that should undergo further evaluation for HNPCC, and the Amsterdam criteria aimed at uniform classification of HNPCC families [19-21]. Our study focused on individuals with disease predisposing mismatch repair (MMR) gene mutations, also referred to as Lynch syndrome. International criteria for surveillance of HNPCC families with MMR gene mutations have been published and adopted by the International Society for Hereditary Gastrointestinal Tumors [5,6]. These guidelines recommend colonoscopy biannually from age 2025 and gynecological examinations with transvaginal ultrasound and endometrial biopsies annually from age 30-35. Whereas colonoscopy surveillance in this high risk population has been proven cost effective, the value of the gynecological surveillance remains unclear $[22,23]$. Indeed, the high risks of endometrial and ovarian cancer may affirm prophylactic hysterectomy with concomitant oophorectomy after child bearing age $[6,24]$. Also, the value of gastric cancer and upper tract urothelial cancer surveillance remains unclear, but intervention is recommended from 30-35 years, in families were these tumor types have occurred $[6,25]$.

At risk individuals in HNPCC families are dependent on health care for diagnosis and surveillance, but several studies have suggested that these individuals perceive a lack of knowledge from health care personnel [1,26-28].
We therefore distributed a questionnaire containing key statements related to knowledge of cancer risks and surveillance strategies to mutation carriers in HNPCC families and to physicians in surgery, gynecology and oncology, who are likely to diagnose, treat and survey these families.

\section{Methods Questionnaire}

The questionnaire contained 11 statements related to colorectal cancer in general (questions 1 and 3), HNPCC cancer risk (questions 2, 4 and 5), surveillance (questions 6 and 7), heredity (questions 8 and 11) and genetic testing (questions 9 and 10); the statements were to be marked "true" or "false" (Additional file 1). Demographic data were also collected. The questionnaire distributed to the physicians also contained questions related to risk levels (<5\%, 5-20\%, 20-40\%, 40-60\%, 60-80\% and >80\%) for colorectal cancer, endometrial cancer, ovarian cancer, gastric cancer and upper tract urothelial cancer and initiation age $(20-25,25-35,35-45$ or $>45$ years) for surveillance programmes of HNPCC associated cancers.

\section{Participants}

The questionnaire and a letter of invitation to the study were mailed to 88 individuals with HNPCC predisposing MMR gene mutations. All individuals had undergone genetic counseling and testing at Lund University Hospital between 1996 and 2008. They had been recommended surveillance programmes at their local hospitals and those diagnosed after 2003 also received a HNPCC information booklet. Data were obtained from 67 (76\%) individuals without differences in age, sex or time since genetic counseling for responders and non responders. Among the responders the median age was $49(22-81)$ years with 38 (57\%) being female and 19 (28\%) representing index individuals in their families. Educational level was elementary school in $27 \%$, high school in $31 \%$, university in $27 \%$ and other in $15 \%$ of the at risk individuals. The median time since genetic counseling was $4(0-12)$ years and $28(42 \%)$ had a personal history of cancer.

In total, 103 physicians from 6 departments ( 2 university hospitals and 3 regional hospitals) in the southern Sweden health care region were invited to participate during staff meetings. After filling out the questionnaire, the authors presented updated guidelines for identification, genetic testing and surveillance of HNPCC. Responses were obtained from 102 (99\%) physicians, with a median age of 47 (22-64) years and 48 (47\%) being female. Specialization was surgery in $40 \%$, gynecology in $29 \%$ and oncology in $30 \%$ of the informants. The physicians reported median $12(0-39)$ years in clinical practise. $72 \%$ worked at regional hospitals and $28 \%$ were employed at a university hospital. 
Ethical approval for the study was granted from the Lund University ethics committee (346/2007).

\section{Statistical analysis}

STATA (StataCorp. 2005. Stata Statistical Software: Release 9. College Station, TX: StataCorp LP) was used for the statistical analyses. For each of the eleven questions, the Chisquared test was used for comparison of the fraction of correct answers among mutation carriers and physicians, whereas Kruskal-Wallis test was applied to compare the distribution of correct answers (range 0-11) in two or more groups. Linear regression was used for multivariate analysis. Unanswered questions were interpreted as missing values. All tests were two-tailed and p-values $<0.05$ were considered significant.

\section{Results}

\section{Key statements among at risk individuals}

The median number of correctly answered questions was 9 (3-11) of 11 (Additional file 1). Questions about colorectal cancer in general, HNPCC associated cancer risk and genetic testing had a high number of correct answers. Questions 3 (individuals not carrying a HNPCC mutation will never develop colorectal cancer) and 7 (individuals that carry HNPCC mutations need regular colonoscopies) had the highest frequencies, 99\% and 96\%, of correct answers. Knowledge about risks for other cancer types and mecha- nisms of inheritance was less accurate; half (52\%) of the mutation carriers marked the risk of inheriting a MMR mutation as 25\% (question 8, correct answer being 50\%) and two thirds $(63 \%)$ recognized that female family members are at increased risk of ovarian cancer (question $5)$. Young age ( $<57$ years), female sex and shorter time since genetic counseling significantly correlated with better results in univariate and multivariate analysis (Table 1 ). The youngest age group answered $84 \%$ of the questions correctly, compared to $71-72 \%$ among individuals $>57$ years $(\mathrm{p}=0.02$; three group comparison). Females answered $81 \%$ of the questions correctly, compared to $71 \%$ in males $(\mathrm{p}=0.01)$. Also, time since genetic counseling was significantly associated with the results, with better knowledge among individuals who underwent genetic counseling within the last 6 years $(p=0.02$; three group comparison). Sex, age and time since genetic counseling explain $32 \%$ of the variability of correct answers ( $\mathrm{R}^{2}$ from multivariate analysis). Education, previous cancer diagnosis and status as index individual did not significantly influence the results.

\section{Key statements among physicians}

The median number of correctly answered questions among the physicians was 9 (5-11) (Additional file 1). Questions about cancer risk, colonoscopies, and genetic testing (questions 3, 6, 9 and 10) were correctly answered

Table I: Characteristics of mutation carriers in relation to correct answers

\begin{tabular}{|c|c|c|c|c|}
\hline Characteristics & Number of individuals & Correct answers & Kruskal-Wallis Test & Multivariate analysis \\
\hline & $\mathrm{n}=67$ & Total (\%) & $\mathrm{P}$-value & p-value* \\
\hline Overall & 67 & $562(76 \%)$ & & \\
\hline Age $(22-8 I)$ & & & 0.02 & 0.001 \\
\hline$\leq 45$ years & 25 & $230(84 \%)$ & & \\
\hline $46-56$ years & 21 & 167 (72\%) & & \\
\hline$\geq 57$ years & 21 & 165 (7I\%) & & \\
\hline Sex & & & 0.01 & 0.002 \\
\hline Female & 38 & $337(81 \%)$ & & \\
\hline Male & 29 & 225 (7I\%) & & \\
\hline Education & & & 0.51 & \\
\hline Elementary school & 17 & | 33 (7|\%) & & \\
\hline High School & 21 & 177 (77\%) & & \\
\hline University & 18 & $160(81 \%)$ & & \\
\hline Other/no data & II & 92 (76\%) & & \\
\hline Index person & & & 0.29 & \\
\hline Yes & 19 & 166 (79\%) & & \\
\hline No & 48 & $396(75 \%)$ & & \\
\hline Time since genetic counseling $(0-I I)$ & & & 0.08 & 0.02 \\
\hline$\leq 3$ years & 26 & $231(8 \mid \%)$ & & \\
\hline 4-6 years & 23 & $192(76 \%)$ & & \\
\hline$\geq 7$ years & 18 & $139(70 \%)$ & & \\
\hline Previous cancer & & & 0.31 & \\
\hline Yes & 28 & $230(75 \%)$ & & \\
\hline No & 39 & 332 (77\%) & & \\
\hline
\end{tabular}

*Linear regression model with answers as the dependent variable and age, time since genetic counseling and sex as independent variables 
by $90-100 \%$ and for most of the statements the results were similar between family members and physicians. Compared to family members, physicians significantly more often gave correct answers to questions 6, 7 and 9 (which related to colonoscopies and tumor tissue for diagnostic purposes), but scored significantly worse than the family members on question 8: individuals with HNPCC will pass the mutated gene on to $25 \%$ (1 in 4) of their children. Only $30 \%$ of the physicians indicated that this was wrong. Regarding the risk of endometrial cancer, $77 \%$ indicated a risk for endometrial cancer and $61 \%$ indicated a risk for ovarian cancer. There were no significant differences in the outcome in relation to specialization (i.e. surgery, gynecology or oncology), employment at a university hospital or a regional hospital, sex or age.

\section{Risk and surveillance strategies among physicians}

The questions on cancer risk and surveillance posed to the physicians, demonstrated suboptimal knowledge, but did not correlate with characteristics such as age, sex and time in practise. The cumulative cancer risks were correctly indicated by less than half of the physicians; $45 \%$ for colorectal cancer, $18 \%$ for endometrial cancer, $43 \%$ for ovarian cancer, 39\% for gastric cancer and 54\% for upper tract urothelial cancer (Figure 1). Only 53\% correctly indicated the initiation age for colonoscopies and 38\% for gynecological cancer. Though surveillance for gastric cancer and upper tract urothelial cancer remains controversial, current guidelines suggest initiation at age 30-35 in affected families, whereas the majority indicated a starting

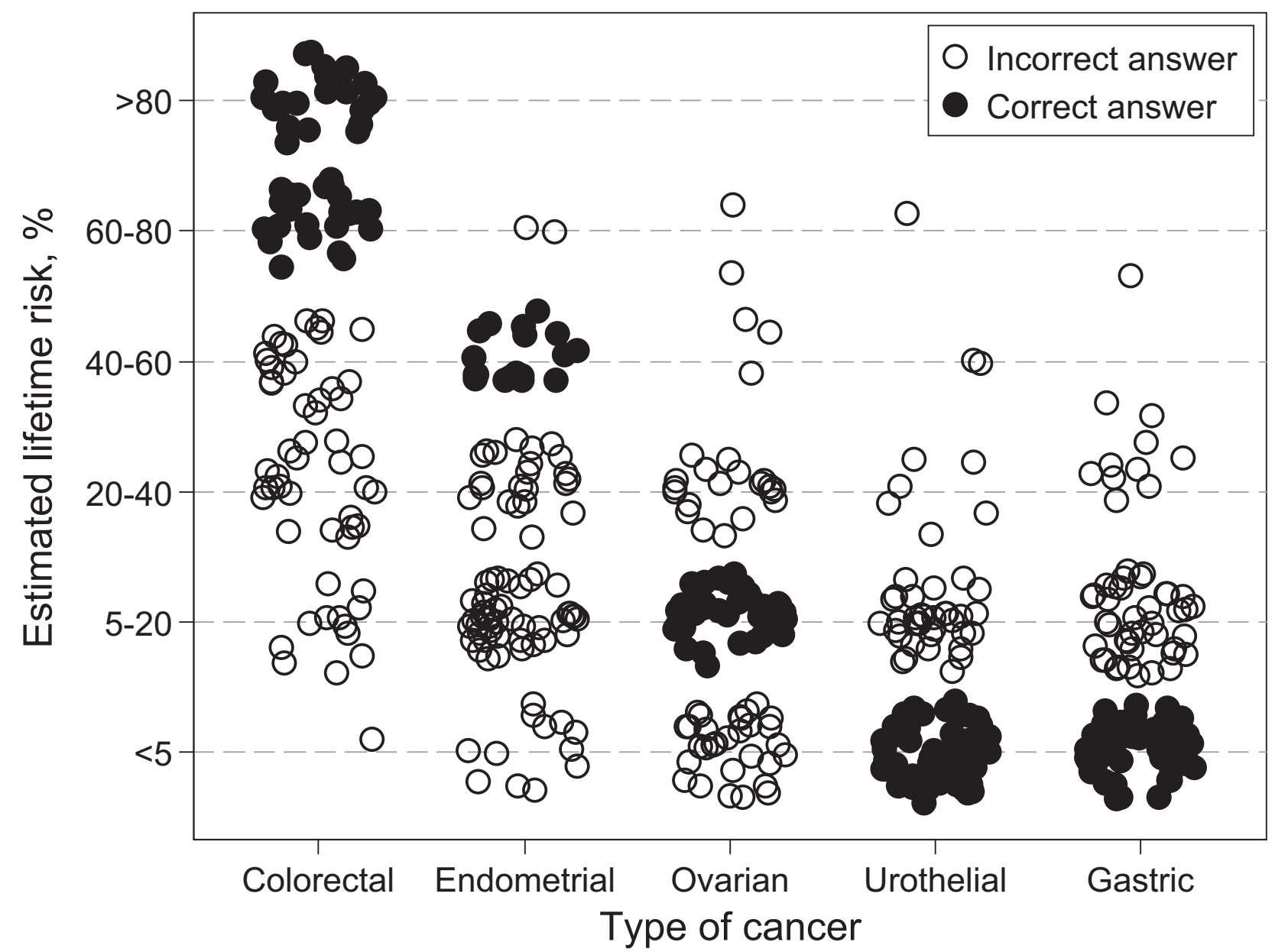

Figure I

Scatter plot of physicians estimation of the lifetime risk of various HNPCC-associated cancer types. The physicians generally underestimated the risk of the common types of HNPCC-associated cancers; with $56 \%$ underestimating the risk of colorectal cancer and $77 \%$ of endometrial cancer. Ovarian cancer was underestimated by $29 \%$ and overestimated by $25 \%$. The risks of rare tumor types were, on the other hand, generally overestimated; by $41 \%$ for upper tract urothelial cancer and $47 \%$ for gastric cancer. For visual purpose, independent random errors, drawn from a uniform distribution on a circle with centre $(0,0)$, have been added to the responses. 
age $>45$ years, which is higher than recommended in any guideline.

\section{Discussion}

After the identification of disease predisposing MMR gene mutations in the early 1990'ies, genetic testing for HNPCC was established. Clinical geneticists and genetic counselors were educated, but the translation of knowledge and implementation among physicians responsible for diagnostics and surveillance has in many instances been difficult [27-29]. An increasing number of healthy at risk individuals now undergo genetic testing and though not formally patients, these individuals are dependent on health care for early cancer prevention. Individuals in HNPCC families often have experience of cancer, if not personal, perhaps in close family members. Their experiences and the vast amount of information available, not least on the internet, make them well educated with extensive knowledge about HNPCC. They thereby provide a challenge to the responsible physician and previous studies suggest that they perceive a lack of professional knowledge when discussing risks and preventive strategies with health care personnel [30].

The key statements used to assess knowledge about HNPCC revealed surprisingly similar results for at risk individuals and physicians (Additional file 1). Physicians scored significantly better on questions related to surveillance and diagnostics (questions 6, 7 and 9). Both groups revealed weaknesses related to mechanisms of inheritance as exemplified by $70 \%$ of the physicians answering that " 1 of 4 children will inherit the mutated gene" (which is wrong since this figure applies to recessive disorders and the correct answer is $50 \%$ in dominantly inherited disorders). Only $30 \%$ of the physicians and $52 \%$ of the family members correctly answered this statement, and the result was indeed significantly better in the family members. Also, $25 \%$ of family members and physicians alike answered that male inheritance is more common, which is wrong since no sex difference applies to autosomal inherited disorders. The demonstration of equal and in some instances better knowledge among members of hereditary cancer families, than among physicians responsible for the management of at risk individuals, is likely to influence trust and satisfaction. These findings are in line with indications of dissatisfaction on behalf of the patients and likely to reflect frustration among physicians. Since experience among physicians did not influence the result, education in genetic medicine probably needs to be improved during medical education.

Two thirds of physicians and family members alike failed to recognize the increased risk of ovarian cancer in HNPCC, which may be related to the more recent focus on the $10-15 \%$ risk of this tumor type in female carriers.
This issue, however, reflects the need to establish ways to reach out with new information to families and responsible physicians. In order to optimize management of these families, reassurance that the individual has understood the information and distribution of printed information which can be brought home and shared with other family members seem efficient. Among the mutation carriers, older individuals and males had a significantly lower number of correct scores, which may indicate that these groups need to receive information in other ways. There was also a trend for higher scores in individuals who had undergone genetic counseling within 6 years compared to those counseled a longer time ago, which may imply a need for information update; many family members ask for possibilities to learn about recent research findings related to HNPCC.

The additional questions posed to the physicians regarding surveillance programmes demonstrated that 3 out of 4 estimated a later starting age and a longer time between the examinations than recommended $[5,6]$. Surveillance for colorectal cancer is based on consistent results from several well designed and well performed studies, whereas there is yet insufficient evidence to support the other surveillance programmes for gynecological cancer, upper tract urothelial cancer and gastric cancer. Knowledge about the evidence and recommendations according to current international guidelines is central for physicians responsible for diagnosis and clinical management of HNPCC. Though we cannot exclude poorer results in the health care region where the data were collected, several recent studies demonstrate insufficient knowledge about hereditary cancer among physicians $[27,29,31]$. A comprehensive evaluation of knowledge and management of hereditary cancer, including different regions and health care systems, is called for in order to determine strategies for improved education which may lead to refined future diagnostics and management of HNPCC family members.

\section{Conclusion}

In summary, this study reveals weaknesses in HNPCC knowledge, particularly among physicians. By tradition, the medical perspective dominates and decides on relevant and evidence based interventions. When a majority of the physicians misinterpret hereditary mechanisms, underestimate the risk of cancer, and fail to recognize HNPCC associated tumor types the likelihood of misinformation is high. Physician behaviour may also influence patient adherence to surveillance programmes, and our findings strongly suggest that improved education in genetic medicine is needed for physicians responsible for diagnosis and management of the growing number of individuals at increased risk of cancer [31-33]. 


\section{Competing interests}

The authors declare that they have no competing interests.

\section{Authors' contributions}

$\mathrm{CC}$ and $\mathrm{MN}$ conceived the idea of this study. CC, MN and $\mathrm{KD}$ constructed the model. KD and PB analyzed the data and interpreted the results. KD drafted the manuscript. All authors revised the paper and approved the final version. All authors take public responsibility of this paper.

\section{Additional material}

\section{Additional file 1}

Table. Questionnaire statements and number (\%) of correct answers. Click here for file

[http://www.biomedcentral.com/content/supplementary/14712350-10-30-S1.xls]

\section{Acknowledgements}

The questionnaire was generated by the authors of this paper with inspiration from Mary J Esplen, University of Toronto. The authors would like to thank the departments of oncology, surgery and gynecology, Lund University Hospital, the department of gynecology and surgery, Halmstad hospital, and the department of surgery, Kristianstad hospital, for their participation in this study. Financial support was granted from the Nilsson Cancer Fund.

\section{References}

I. Hadley DW, Jenkins JF, Dimond E, de Carvalho M, Kirsch I, Palmer CG: Colon cancer screening practices after genetic counseling and testing for hereditary nonpolyposis colorectal cancer. J Clin Oncol 2004, 22(I):39-44.

2. Wagner A, Tops C, Wijnen JT, Zwinderman K, Meer C van der, Kets M, Niermeijer MF, Klijn JG, Tibben A, Vasen HF, et al.: Genetic testing in hereditary non-polyposis colorectal cancer families with a MSH2, MLHI, or MSH6 mutation. J Med Genet 2002, 39(I I):833-837.

3. Chen LM, Yang KY, Little SE, Cheung MK, Caughey AB: Gynecologic cancer prevention in Lynch syndrome/hereditary nonpolyposis colorectal cancer families. Obstet Gynecol 2007, I I O(I): 18-25.

4. Lancaster JM, Powell CB, Kauff ND, Cass I, Chen LM, Lu KH, Mutch DG, Berchuck A, Karlan BY, Herzog TJ: Society of Gynecologic Oncologists Education Committee statement on risk assessment for inherited gynecologic cancer predispositions. Gynecol Oncol 2007, I07(2): I59-162.

5. Vasen HF, Moslein G, Alonso A, Bernstein I, Bertario L, Blanco I, Burn J, Capella G, Engel C, Frayling I, et al.: Guidelines for the clinical management of Lynch syndrome (hereditary non-polyposis cancer). J Med Genet 2007, 44(6):353-362.

6. Lindor NM, Petersen GM, Hadley DW, Kinney AY, Miesfeldt S, Lu $\mathrm{KH}$, Lynch P, Burke W, Press N: Recommendations for the care of individuals with an inherited predisposition to Lynch syndrome: a systematic review. JAMA 2006, 296(I 2): I507-I5 I7.

7. Claes E, Denayer L, Evers-Kiebooms G, Boogaerts A, Legius E: Predictive testing for hereditary non-polyposis colorectal cancer: motivation, illness representations and short-term psychological impact. Patient Educ Couns 2004, 55(2):265-274.

8. Vernon SW: Risk perception and risk communication for cancer screening behaviors: a review. J Natl Cancer Inst Monogr 1999:101-119.

9. de la Chapelle A: The incidence of Lynch syndrome. Fam Cancer 2005, 4(3):233-237.

10. Aarnio M, Sankila R, Pukkala E, Salovaara R, Aaltonen LA, de la Chapelle A, Peltomaki P, Mecklin JP, Jarvinen HJ: Cancer risk in mutation carriers of DNA-mismatch-repair genes. Int J Cancer 1999, 8 I(2):214-218.

II. Barrow E, Alduaij W, Robinson L, Shenton A, Clancy T, Lalloo F, Hill J, Evans DG: Colorectal cancer in HNPCC: cumulative lifetime incidence, survival and tumour distribution. A report of I 2 I families with proven mutations. Clin Genet 2008, 74(3):233-242.

12. Dunlop M, Campbell H: Screening for people with a family history of colorectal cancer. BMJ I997, 3 | 4(7097): I 779- I 780.

13. Dunlop MG, Farrington SM, Carothers AD, Wyllie AH, Sharp L, Burn J, Liu B, Kinzler KW, Vogelstein B: Cancer risk associated with germline DNA mismatch repair gene mutations. Hum $\mathrm{Mol}$ Genet 1997, 6(1): 105-110.

14. Watson P, Butzow R, Lynch HT, Mecklin JP, Jarvinen HJ, Vasen HF, Madlensky L, Fidalgo P, Bernstein I: The clinical features of ovarian cancer in hereditary nonpolyposis colorectal cancer. Gynecol Oncol 2001, 82(2):223-228.

15. Vasen HF, Sanders EA, Taal BG, Nagengast FM, Griffioen G, Menko $\mathrm{FH}$, Kleibeuker JH, Houwing-Duistermaat J, Meera Khan P: The risk of brain tumours in hereditary non-polyposis colorectal cancer (HNPCC). Int J Cancer 1996, 65(4):422-425.

16. Vasen HF, Wijnen JT, Menko FH, Kleibeuker JH, Taal BG, Griffioen G, Nagengast FM, Meijers-Heijboer EH, Bertario L, Varesco L, et al.: Cancer risk in families with hereditary nonpolyposis colorectal cancer diagnosed by mutation analysis. Gastroenterology 1996, I I 0(4): 1020-1027.

17. Sijmons RH, Kiemeney LA, Witjes JA, Vasen HF: Urinary tract cancer and hereditary nonpolyposis colorectal cancer: risks and screening options. J Urol 1998, I 60(2):466-470.

18. Murphy HR, Armstrong R, Cairns D, Greenhalgh KL: Muir-Torre Syndrome: expanding the genotype and phenotype - a further family with a MSH6 mutation. Fam Cancer 2008, 7(3):255-257.

19. Vasen HF, Watson P, Mecklin JP, Lynch HT: New clinical criteria for hereditary nonpolyposis colorectal cancer (HNPCC, Lynch syndrome) proposed by the International Collaborative group on HNPCC. Gastroenterology |999, I | 6(6): | 453- | 456.

20. Rodriguez-Bigas MA: Genetic testing is important in families with a history suggestive of hereditary non-polyposis colorectal cancer even if the Amsterdam criteria are not fulfilled. BrJ Surg 1997, 84(7): 1027-1028.

21. Umar A, Boland CR, Terdiman JP, Syngal S, de la Chapelle A, Ruschoff J, Fishel R, Lindor NM, Burgart LJ, Hamelin R, et al.: Revised Bethesda Guidelines for hereditary nonpolyposis colorectal cancer (Lynch syndrome) and microsatellite instability. J Natl Cancer Inst 2004, 96(4):26I-268.

22. Vasen HF, van Ballegooijen M, Buskens E, Kleibeuker JK, Taal BG, Griffioen G, Nagengast FM, Menko FH, Meera Khan P: A cost-effectiveness analysis of colorectal screening of hereditary nonpolyposis colorectal carcinoma gene carriers. Cancer 1998, 82(9): | 632-1637.

23. Jarvinen HJ, Aarnio M, Mustonen H, Aktan-Collan K, Aaltonen LA, Peltomaki P, De La Chapelle A, Mecklin JP: Controlled I5-year trial on screening for colorectal cancer in families with hereditary nonpolyposis colorectal cancer. Gastroenterology 2000, I | 8(5):829-834.

24. Schmeler KM, Lynch HT, Chen LM, Munsell MF, Soliman PT, Clark MB, Daniels MS, White KG, Boyd-Rogers SG, Conrad PG, et al.: Prophylactic surgery to reduce the risk of gynecologic cancers in the Lynch syndrome. N Engl J Med 2006, 354(3):26I-269.

25. Hendriks YM, de Jong AE, Morreau H, Tops CM, Vasen HF, Wijnen JT, Breuning $\mathrm{MH}$, Brocker-Vriends $\mathrm{AH}$ : Diagnostic approach and management of Lynch syndrome (hereditary nonpolyposis colorectal carcinoma): a guide for clinicians. CA Cancer J Clin 2006, 56(4):213-225.

26. Johnson KA, Trimbath JD, Petersen GM, Griffin CA, Giardiello FM: Impact of genetic counseling and testing on colorectal cancer screening behavior. Genet Test 2002, 6(4):303-306.

27. Batra S, Valdimarsdottir H, McGovern M, Itzkowitz S, Brown K: Awareness of genetic testing for colorectal cancer predisposition among specialists in gastroenterology. Am J Gastroenterol 2002, 97(3):729-733.

28. Schroy PC 3rd, Barrison AF, Ling BS, Wilson S, Geller AC: Family history and colorectal cancer screening: a survey of physician knowledge and practice patterns. Am J Gastroenterol 2002, 97(4): $103 \mid-1036$. 
29. Hes FJ: Lynch syndrome: still not a familiar picture. World J Surg Oncol 2008, 6:21.

30. Lynch PM: New issues in genetic counseling of hereditary colon cancer. Clin Cancer Res 2007, I3(22 Pt 2):6857s-686Is.

31. Wideroff L, Vadaparampil ST, Greene MH, Taplin S, Olson L, Freedman AN: Hereditary breast/ovarian and colorectal cancer genetics knowledge in a national sample of US physicians. J Med Genet 2005, 42(10):749-755.

32. Tinley ST, Houfek J, Watson P, Wenzel L, Clark MB, Coughlin S, Lynch HT: Screening adherence in BRCAI/2 families is associated with primary physicians' behavior. Am J Med Genet A 2004, I 25A(I):5-II.

33. Gilbert A, Kanarek N: Colorectal cancer screening: physician recommendation is influential advice to Marylanders. Prev Med 2005, 4 I (2):367-379.

\section{Pre-publication history}

The pre-publication history for this paper can be accessed here:

http://www.biomedcentral.com/1471-2350/10/30/pre pub

Publish with Bio Med Central and every scientist can read your work free of charge

"BioMed Central will be the most significant development for disseminating the results of biomedical research in our lifetime. "

Sir Paul Nurse, Cancer Research UK

Your research papers will be:

- available free of charge to the entire biomedical community

- peer reviewed and published immediately upon acceptance

- cited in PubMed and archived on PubMed Central

- yours - you keep the copyright

Submit your manuscript here:

http://www.biomedcentral.com/info/publishing_adv.asp 